\title{
Constitutionality of Export Controls
}

It was not until twenty-five years ago ${ }^{1}$ that the federal government embarked upon an extensive program of export regulation. While embargoes had been imposed intermittently since 1794, ${ }^{2}$ never before had export control become a peacetime fixture. The basic statute, the Export Control Act of $1949,{ }^{3}$ not only grants the President authority to

[1.] With the fall of France, Congress granted the President blanket authority to imposc export controls to strengthen the national defense. Army Reorganization Act of July 2, $1940, \S 6,54$ Stat. $712,714(1940)$, as amended.

[2.] During the dispute with England preceding the Jay Treaty, a two month cmbargo was imposed on all shipping in an effort to force Britain to come to terms. SAMUEL Benis, Diplomatic History OF THE UNITED STATES 100-01 (2d ed. 1942).

[3.] 63 Stat. 7 (1948), as amended, 50 U.S.C. App. \$§ 2021-2032 (1964, 1965 Supp.). The export of the following articles is controlled under other statutes:

\begin{tabular}{|c|c|c|}
\hline Articles & Controlling Agency & Statutes and Regulations \\
\hline Armaments & State Department & $\begin{array}{l}\text { Mutual Sccurity Act of 1954, \& } 414 \text {, } \\
68 \text { Stat. } 848(1954) \text {, as amended, } 22 \\
\text { U.S.G. \& 1934 (1964); } 22 \text { C.F.R. } \\
\text { \& 121-22 (1966). }\end{array}$ \\
\hline $\begin{array}{l}\text { Nuclear Material } \\
\text { and Facilities }\end{array}$ & Atomic Energy Commission & $\begin{array}{l}\text { Atomic Energy Act of 1954, } 68 \\
\text { Stat. 939 }(1954) \text {, as amended, } 42 \\
\text { U.S.C. } \$ 2139 \text { (1964); } 10 \text { G.F.R } \\
\$ \$ 36,40.3,40.33,50.10,50.44,70.4 \\
\text { (1963, Supp. 1966). }\end{array}$ \\
\hline Gold & Treasury Department & $\begin{array}{l}\text { Gold Reserve Act of } 1984,48 \text { Stat. } \\
337 \text { (1934), } 31 \text { U.S.C. } \$ 442(1964) ; \\
\text { Act of October 6, 1917, \& } 5(\mathrm{~b}), 40 \\
\text { Stat. } 415(1917), \text { as amended, } 12 \\
\text { U.S.C. } \$ \$ 95(\mathrm{a}), 95(\mathrm{~b})(1964) ; 31 \\
\text { C.F.R. } \$ 54 \text { (1966). }\end{array}$ \\
\hline Narcotics & Treasury Department & $\begin{array}{l}\text { Narcotics \& Drugs Import and Ex- } \\
\text { port Act, } 38 \text { Stat. } 275 \text { (1914), as } \\
\text { amended, 21 US.C. } \$ \$ 182.88 \\
\text { (1964); Int. Rev. Code of 1954, } \\
\text { § 4741. }\end{array}$ \\
\hline $\begin{array}{l}\text { Tobacco Seed and } \\
\text { Live Tobacco Plants }\end{array}$ & Department of Agriculture & $\begin{array}{l}\text { Tobacco Seed and plant Exporta- } \\
\text { tion Act, } 54 \text { Stat. 231 (1940), } 7 \\
\text { U.S.C. } \$ 516 \text { (1964). }\end{array}$ \\
\hline $\begin{array}{l}\text { American Owned } \\
\text { Vessels }\end{array}$ & Maritime Commission & $\begin{array}{l}\text { Shipping Act of } 1916,89 \text { Stat, } 790 \\
\text { (1916), as amended, } 40 \text { Stat, 901 } \\
\text { (1918), as amended, 46 U.S.C. } \\
\$ \S 808,835 \text { (1964); } 46 \text { C.F.R. } \$ 221 \\
\text { (1966). }\end{array}$ \\
\hline Natural Gas & Federal Power Commission & $\begin{array}{l}\text { Natural Gas Act, } 52 \text { Stat. } 822 \\
\text { (1938), } 15 \text { U.S.C. } 8717 \text { b (1964); } 18 \\
\text { C.F.R. \& } 153 \text { (1966). }\end{array}$ \\
\hline
\end{tabular}

The Post Office assists in the enforcement of all of these statutes. Local Postal officials are instructed to check parcels in order to assure compliance. 39 C.F.R. $\$ \$ 141.45$ (1966), promulgated under authority of 1 Stat. 28 (1789), as amended, 5 U.S.C. $\S 22$ (1964); 74 Stat. 580,581 (1960), 39 U.S.C. $\$ \S 501,505(1964)$. 
restrict exports for reasons of national security or foreign policy, but also permits restrictions in the event of domestic shortage." Scarcity at home has caused the Bureau of International Commerce, acting for the President, to restrict the export of goods of considerable importance to the world economy. During the past ten years, iron, steel, aluminum, nickel, and sugar have been on quota for substantial periods. Currently, the list includes copper and shoe leather. ${ }^{\circ}$ This Note argues that quotas of this type, whose only justification is domestic scarcity, violate Article 1, Section 9 of the Constitution"No tax or duty shall be laid on articles exported from any state."

Serious consideration of the constitutional status of export regulation has been discouraged by reference to the embargoes maintained from time to time since the early days of the Republic. But the embargo precedents cannot justify quotas imposed as a tool of commercial

[4.] Export Control Act, $\S \S 1,2 ; 63$ Stat. 7 (1948), as amended, 50 U.S.C. App. $\$ \S$ 2021-22 (1964, 1965 Supp.).

[5.] Export Control Act, $\S 4(a), 63$ Stat. 8, as amended, 50 U.S.C. App. $₹ 2024$ (1965 Supp.), requires the Bureau to consult with those agencies and departments concemed with exports.

[6.] The following list of restricted items was prepared by the Burcau of International Commerce at the request of the Yale Law Joumal Oct. 10, 1966, on file in Yale Law Library:

\begin{tabular}{|c|c|c|}
\hline & From & To \\
\hline $\begin{array}{l}\text { Iron and steel scrap } \\
\text { Diamond Bort } \\
\text { Hog Bristles } \\
\text { Nickel Powder; nickel and nickel } \\
\text { alloy metal; nickel and nickel } \\
\text { bearing scrap; cobalt alloy } \\
\text { nickel scrap; nickel oxide }\end{array}$ & $\begin{array}{l}12 / 8 / 54 \\
\text { (Korean conflict) } \\
\text { (Korean conflict) } \\
\text { (Korean conflict) }\end{array}$ & $\begin{array}{l}\text { 4th Qr. } 1958 \\
\text { 4th Or. } 1958 \\
\text { lst Or. } 1956 \\
\text { 2nd Or. } 1959\end{array}$ \\
\hline Selenium & (Korean conflict) & 4th Qr. 1957 \\
\hline $\begin{array}{l}\text { Aluminum Scrap } \\
\text { Aluminum Primary forms } \\
\text { Unrefined Copper }\end{array}$ & $\begin{array}{l}6 / 11 / 54 \\
4 / 2 / 55 \\
1 / 20 / 66\end{array}$ & $\begin{array}{l}\text { 3rd \& 4th Qrs. } 1957 \\
\text { 3rd \& 4th Qrs. } 1957\end{array}$ \\
\hline $\begin{array}{l}\text { Unrefined Copper } \\
\text { Refined Copper }\end{array}$ & $\begin{array}{r}10 / 19 / 54 \\
1 / 20 / 66\end{array}$ & $\begin{array}{l}\text { 4th Qr. } 1957 \\
\text { Present }\end{array}$ \\
\hline $\begin{array}{l}\text { Copper base alloy igots } \\
\text { Copper scrap (new and old, } \\
\text { unalloyed scrap; copper base } \\
\text { scrap less than 5\% nickel) }\end{array}$ & $\begin{array}{r}1 / 20 / 66 \\
10 / 19 / 54\end{array}$ & $\begin{array}{l}\text { Present } \\
\text { 4th Qr. } 1957\end{array}$ \\
\hline $\begin{array}{l}\text { Copper and copper alloy scrap } \\
\text { Semifabricated copper products } \\
\text { Polio (Salk) vaccine } \\
\text { Rerolling, relaying, and used } \\
\text { steel rails }\end{array}$ & $\begin{array}{l}11 / 24 / 65 \\
1 / 20 / 66 \\
4 / 13 / 55 \\
\text { Sept. } 1956\end{array}$ & $\begin{array}{l}\text { Present } \\
\text { Present } \\
11 / 10 / 58 \\
\text { 4th Qr. } 1958\end{array}$ \\
\hline $\begin{array}{l}\text { Influenza vaccine (Asian Strain) } \\
\text { Beet and cane sugar } \\
\text { Walnut logs, bolts, and hewn timber } \\
\text { Cattle hides, calf and lip skins } \\
\text { and bovine leathers }\end{array}$ & $\begin{array}{l}8 / 15 / 57 \\
6 / 27 / 63 \\
2 / 14 / 64 \\
3 / 7 / 66\end{array}$ & $\begin{array}{l}4 / 2 / 58 \\
10 / 15 / 64 \\
2 / 12 / 65 \\
\text { Present }\end{array}$ \\
\hline
\end{tabular}


policy. Embargoes have been declared either during war, ${ }^{7}$ to punish an unfriendly country by a means short of war, ${ }^{8}$ or to prevent arms shipments from contributing to foreign instability. ${ }^{9}$ But quotas imposed to relieve shortages, like duties on exports, are prompted by domestic concerns.

Moreover, export quotas burden trade at least as much as duties. So long as foreign demand remains constant, a numerical limit on exports obviously inhibits free trade as much as a tax set so that only an equal number will be purchased. And if foreign demand increases, the quota will be more restrictive in that none of the new foreign demand will be satisfied. It is for this reason that the members of the General Agreement on Tariffs and Trade (GATT) have agreed in principle to abolish export quotas, even though they have not reached agreement on duties. ${ }^{10}$ GATT, however, contains a proviso permitting export control in the name of domestic scarcity. ${ }^{11}$ But the Constitution goes farther. Since the Export Clause bans taxes or duties it would be paradoxical to suppose that it permits a technique at lenst as restrictive.

To escape this construction, the Clause could be viewed merely as prohibiting a particular form of taxation, instead of extending broad constitutional protection to the export trade. But the records of the Constitutional Convention reveal a larger purpose. In fact, the delegates voted down an amendment which would have banned only those export duties imposed "for the purpose of revenue." 12 In doing so, the Convention was aware that it was depriving the new government of a tool for both domestic and foreign commercial policy. Some colonial duties had been designed, in part, to funnel domestic raw materials to domestic manufacturers. ${ }^{13}$ Furthermore, it was clear that

[7.] Embargoes have been imposed during every war fought by the United States, with the exception of the Mexican. See BEMIs, op. cit. supra note 2, at 160 (War of 1812), 373 (Civil), 618 (World War I); Elton Atwater, AMERICAN Reguration of Arms Extorts 18 (1941) (Spanish-American War); see also note 1 supra.

[8.] Between 1794 and 1812, the United States frequently imposed embargoes on exports to compel Britain and France to respect its rights as a neutral. ATwATER, op. cit. stupra note 7, at 11-15.

[9.] Id. at 37-38.

[10.] Oct. 30, 1947, art. XI, para. 1, 61 Stat. A3, A32.

[11.] Oct. 30, 1947, art. XX, part II, 61 Stat. A3, A62, as amended [1957] 8 U.S.T. \& O.I.A. 1786-87.

[12.] 2 FARRAND, The Records of the Federal Convention of 1787363 (1987).

[13.] Duties imposed on lumber exports, for example, were largely motivated by colonial efforts to encourage the ship building industry. See ALBERT GIESEGKE, AMERICAN COMMERCIAI LEGISLATION BEFORE 1789 49-53 (1910). Duties were also commonly levied on raw hides to encourage the establishment of tanneries. Id. at 43 . The export of iron ore was occasionally taxed for the sake of domestic foundries. See, e.g., 2 JEREMY BeLKNAP, HistonY OF NEW HAMPSHIRE 29 (1791) (available in the Beinecke Rare Book Library). Maryland 
a stiff tax on exports would have helped persuade England to open West Indian ports to American shipping. ${ }^{1 *}$ Still, the delegates refused to accept the proposed limitation on the Clause. They also rejected a second amendment, which permitted export taxes if approved by a two-thirds majority in both Houses. ${ }^{15}$ In leaving the Export Clause intact, the Convention reached a deliberate decision to prohibit the government from burdening the export trade in any way.

Today, it may seem careless of delegates to have mentioned only "taxes" and "duties," ignoring other burdens on exports. But no other type of regulation was used by the states during the fifty years preceding the Convention. During the seventeenth century the colonies had sporadically imposed total embargoes for commercial reasons, but by the eighteenth century this technique had been abandoned; ${ }^{10}$ nor was the administration of a system of export quotas within the bureaucratic talents of our forebears.17 Thus, by 1789 , the chief restrictive devices used by the states were export and tonnage duties, ${ }^{18}$ and the Convention removed these obstacles in the Export Clause. The only other type of export restriction which the delegates had experienced was the English Navigation Acts. These acts took a variety of forms, but in essence they required the colonists to ship their exports of certain "Enumerated Commodities" through England where a tax was imposed before the goods could be transshipped to their European purchasers. ${ }^{10}$ The Constitutional provision immediately following the Export Clause prevents the federal government from granting one section

intermittently imposed pig iron ore duties during the period of Confederation. 1 Jounsox,

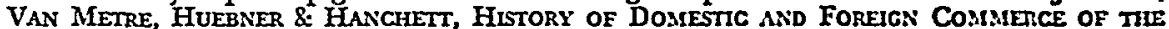
UNIIED STATES 140 (1915). Maryland and Virginia imposed revenue duties on tobacco at the time of the Convention. Ibid. For a more detailed account of the tobaceo tax, sce GIESECEE, op. cit. supra, at $45-49$.

[14.] VernoN SETSER, The CoMmercial Reciproctry Policy of the United States 11741829100 (1937).

[15.] 2 FARRAND, op. cit. supra note 12, at 363.

[16.] GIESECKE, op. cit. supra note 13, at 80-82. Mr. Giesecke claims that New Hampshire imposed an embargo upon iron ore in 1719 to aid an iron works. A search of contemporar; sources indicates, however, that the state only levied duty of ten pounds on each ton exported. See 2 BELKNAP, op. cit. supra note 13, at 29.

[17.] A leading historian describes the colonial customs service:

Collectors were constantly charged with a great variety of misdemeanors-illegal trading, connivance at illegal trade, compounding breaches of the law, accepting brides and excessive fees and handing in imperfect and even erroncous accounts-but accusations, true and false, and offenses, great and small, were to be expected in connection with so large a body of men, often untrained, ignorant, and mediocre, underpaid and overworked, and engaged in carrying out, within districts that were generally too large for any one man to cover, an unpopular code of commercial law ....

4 Charles Andrews, The Colonlal Period of Amierican History 208 (1938).

[18.] A tonnage duty is a tax varying with the capacity of the ship. For a discussion of early tonnage duties see generally, GreSECKE, op. cit. supra note 13, at 86-99.

[19.] The system is explained in 4 ANDrEvs, op. cil. supre note 17, at 85-107, 424. 
of the country a comparable position in the export trade by forbidding favoritism of one port over another. The delegates prohibited the threat to exports as it presented itself in the concrete, not in the abstract. They barred duties without considering that other restrictive techniques could flourish in a more regulated society.

If, however, the Convention had foreseen the possibility of more sophisticated restrictions, it would have outlawed them as well, for the aims of the Clause would have been frustrated by quotas as much as by duties. The Export Clause gave the South one of the guarantees it demanded before it would enter the union. Thanks to its prohibition, foreign trade in cotton, rice and tobacco would be insulated from the control of the new government. The economic sources of Southern power would remain secure. ${ }^{20}$ If the federal government had been free to impose export quotas depriving suppliers of lucrative foreign markets, and forcing them to ship to the North at lower prices, Southern autonomy would have been severely compromised and the Export Clause nullified.

Though Southern demands made the Export Clause a political necessity, the Convention intended it to do more than protect the interests of one region. It recognized that "every state might reason with regard to its particular productions, in the same manner as the Southern States. The Middle States may apprehend an oppression of their wheat flour provisions, etc. and with more reason, as these articles were exposed to a competition in foreign markets not incident to tobacco, rice, etc. ${ }^{\prime 21}$ Northern states, ${ }^{22}$ as well as Southern ones, voted against the attempts to weaken the Clause.

Finally, the Clause expressed the free trade policies generally followed by the national government during the period of Revolution and Confederation. ${ }^{23}$ The Model Treaty, adopted by the Continental Congress in 1776 to serve not only as a proposal to France, but as a declaration of principle, offered French citizens all the commercial privileges of Americans, if France would reciprocate. ${ }^{24}$ When in

[20.] Charles Warken, The Making of the Constitution 571.74 (1947).

[21.] 2 Farrand, op. cit. supra note 12, at 363.

[22.] On the motion to limit the prohibition to duties levied for the purposes of revenue, New Hampshire, Massachusetts and Connecticut voted to keep the Clausc intact. Of the northern states, only Connecticut voted against the motion to permit dutics with the consent of two-thirds of Congress. 2 FarRAND, op. cit. supra note 12, at 363.

[23.] For the impact of free trade philosophy on newly independent America, sce Feux GILBERT, To THE FAREWELL AdDRESS 42-43, 54-69 (1961).

[24.] Id. at 54-56. The French rejected the offer and insisted on a conditional most favored nations clause. See Setser, Did Americans Originate the Conditional Most Favored Nations Clause? 5 J. OF MODERN HISTORY 319 (1933). 
1784, the Confederation embarked on an effort to negotiate commercial treaties with the European powers, the principles of the Model Treaty were reaffirmed.25

The Export Clause should serve similar functions today-protecting domestic producers and advancing free trade. Export quotas, like export duties, can be used for the benefit of manufacturers at the expense of primary producers. The transfer occurs without the use of the highly visible taxing power, and without any need to grant a controversial subsidy. Furthermore, quotas provide the easiest way of retreating from the goal of freer trade. When an increased import tariff is proposed, the interest of a large class of consumers is clearly threatened. At the very least, a politician would make a sober appraisal of the proposal before supporting protection. Not so with an export quota. Its effect on consumers is invisible and roundabout. As a quota increases supply available on the domestic market, at least temporarily, the consumer gains in the short run. The risk of reprisal and the general principle of comparative advantage may often remain in the background. Thus the Clause can serve its historic purpose by foreclosing modern restrictions on the export trade.

Even if the contemporary importance of the Export Clause is granted, remembrance of things past may prompt suggestions that the Court should avoid all intervention in the formulation of national economic policy. But a casual reference to the Old Court and the New Deal does not dispose of the problem. For the Export Clause does not invite the Court to explore the vague contours of the due process clause or the penumbras of the Fourth Amendment, nor to second-guess the "reasonableness" of legislation. Rather, its mandate resembles that of the Commerce Clause, which the Court has used to protect free trade among the states without arousing cries of judicial usurpation..$^{26}$ The Export Clause can be invoked to the same effect.

[25.] GILBERT, op. cit. supra note 23, at 70. This campaign also was a failure. SEsten, op. cit. supra note 14, at 74-81.

[26.] Under the Commerce Clause cases, the states are generally prohibited from burdening interstate more than domestic commerce. While a state may impose an income tax upon an interstate business, it must apply it non-discriminatorily, and only upon the income earned within the state. Northwestem States Portland Cement Co. v. Mlinnesota, 358 U.S. 450 (1959). In a limited number of situations, a state has been permitted to discriminate against out-of-state interests on the ground that the state had a property interest in the resource protected. McCready v. Virginia, 94 U.S. 391 (1877). But this argument has had little success in twentieth century decisions. Pennsylvanis v. West Virginia, 262 U.S. 553 (1923); Toomer v. Witsell, 334 U.S. 385 (1948).

For general discussions of the area see, Hartman, State Taxation of Interstate Commerce: A Survey and an Appraisal, 46 VA. L. REv. 1051 (1960); Barrett, State Taxation of Inter. state Commerce- "Direct Burdens," "Multiple Burdens," or What Have You? 4 VAsio. $L$. REv. 496 (1951). 
Even in the limited area of export control, judicial intervention will not totally disable the government. In extremis, the government could offer to buy substantial quantities of the product from domestic producers at a price exceeding the world market price. Of course, this would require a greater expenditure of political, as well as economic, capital. The greater cost, however, will encourage a more intensive scrutiny of export regulation with an eye to the matter of principle at stake. Thus, in invoking the Export Clause the Court would be performing the educational function for which it is ideally suited.

In declaring certain quotas unconstitutional, the Court would not be constructing constitutional principles out of whole cloth. Rather, it would follow the course of Export Clause adjudication. In Fairbank v. United States, ${ }^{27}$ the Court invalidated a stamp tax which levied ten cents on each export bill of lading, recognizing that if a nominal tax were justified, a more considerable burden could constitutionally be placed on exports. Reaching the basic principles at stake, the Court denied that the Clause merely prohibited levies designed to raise revenue or those aimed at the exports of one region. Rather, Fairbank held that "the requirement of the Constitution is that exports should be free from any governmental burden." 28 Nor was the Court impressed by the fact the tax was imposed on the bill of lading and was not levied on the export directly. In its view, "The form in which the burden is imposed cannot vary the substance."29

Fourteen years later, the Supreme Court reaffirmed Fairbank in companion decisions. It struck down both a tax on policies insuring against the risks of foreign shipping ${ }^{30}$ and a tax on foreign charter parties. ${ }^{31}$ Writing for the Court, Chief Justice Hughes used a rationale which outlaws quotas as surely as it does all forms of montetary burden:

This constitutional freedom, however, plainly involves more than mere exemption from taxes or duties which are laid specifically upon the goods themselves. If it meant no more than that, the obstructions to exportation which it was the [Clause's] purpose to prevent could readily be set up by legislation nominally conforming to the constitutional restriction but in effect overriding it. ${ }^{32}$

[27.] 181 U.S. 283 (1901).

[28.] Id. at 290 .

[29.] Id. at 295 .

[30.] Thames \& Mersey Marine Ins. Co. v. United States, 237 U.S. 19 (1915).

[31.] United States v. Hvoslef, 237 U.S. 1 (1915).

[32.] Id. at 13. The more recent decisions have considered problems not relevant to the constitutional status of export quotas. A. G. Spalding \& Bros. v. Edwards, 262 U.S. 66 (1923), held a sale to a broker, buying on behalf of a foreign customer, was an "cxport" and could not be taxed. See also Richfield Oil Corp. v. State Bd. of Equalization, 329 U.S. 69 (1946). William E. Peck \& Co. v. Lowe, 247 U.S. 165 (1918), refused to permit an exporter 
Though existing quotas are unconstitutional, it may be possible to validate future restrictions by use of the treaty power. Whether a treaty can override specific constitutional restrictions remains unclear. While Supreme Court dicta may be found insisting that the Constitution's "thou shalt nots" may in no event be overridden, ${ }^{33}$ Missourri $v$. Holland $^{34}$ indicates that at least some provisions can be. In Holland the Court assumed that a federal statute regulating the hunting of migratory birds would be unconstitutional, but nevertheless upheld such a statute enforcing a Migratory Bird Treaty negotiated with Canada. Central to the Court's reasoning, however, was the fact that the treaty did "not contravene any prohibitory words to be found in the Constitution. The only question is whether it is forbidden by some invisible radiation from the general terms of the Tenth Amendment." Consequently Holland cannot stand as a direct precedent supporting a treaty whose provisions contravened the Export Clause. Indeed, Holland's continuing vitality seems questionable. It may well be that Justice Holmes resorted to an expansive conception of the treaty power as the only way to save a federal statute whose constitutionality was doubtful given the prevailing insistence on states' rights. With the demise of Tenth Amendment jurisprudence an appeal to the treaty power would no longer be necessary to save the birds.

But still, the treaty power may justify some export quotas, particularly since some treaties may actually further the policies behind the Export Clause. For example, multinational efforts to stabilize world commodity prices would neither frustrate the goal of world economic development nor impoverish commodity producers. Indeed, the long term interests of primary producers may well be served by export restrictions imposed in the name of income stabilization. It is clear that though the Convention did intend to proscribe all burdens on

to use the Export Clause to avoid the reach of the Internal Revenue Service. The court held that a general, non-discriminatory income tax was only an "indirect" burden upon exports. Id. at 175. See also Canton R.R. v. Rogan, 340 U.S. 511 (195I), Western Mrarjland Ry. v. Rogan, 340 U.S. 520 (1951); Northwestern States Portland Cement Co. v. Mlinnesota, 358 U.S. 450 (1959).

[33.] The treaty power, as expressed in the Constitution, is in terms unlimited except by those restraints which are found in that instrument against the action of the government or of its departments, and those arising from the nature of the government itself and of that of the states. It would not be contended that it extends so far as to authorize what the Constitution forbids, or a change in the character of the government or in that of one of the states, or a cession of any portion of the territory of the latter without its consent.

Geofroy v. Riggs, 133 U.S. 258, 267 (1890) (Field, J.). (Emplussis added.) See Reid v. Covert, 354 U.S. 1, 6 (1957). But cf. TVilson v. Girard, 354 U.S. 524 (1957). See generally, Sutherland, Restricting the Treaty Power, 65 HARv. L. REv. 1305, 1312-20 (1952).

[34.] 252 U.S. 416 (1920).

[35.] Id. at 433-34. 
exports, it did not imagine that short term limitations could further the long term development of international trade.

Obviously, the Court lacks the competence necessary to determine whether a given arrangement aids or inhibits trade in the long run. Nor is the spectre of searching judicial review likely to facilitate international negotiation. Consequently, the Court should only strike down blatant attempts to avoid the Export Clause through the use of the treaty form. ${ }^{36}$ It should, however, insist that the agreement in question is in fact a treaty, approved by two-thirds of the Senate, and not a unilateral executive decision.

It may also be that a limited range of statutory export controls would not contravene the policies of the Clause. Where the government imposes a burden on the domestic trade in a product it should be permitted to impose an equal burden on its international trade. Here it would be unreasonable to assume that the law is discriminating against exports. A ban on foreign trade in heroin is not imposed to force producers to sell more cheaply at home.

Finally, controls initiated to further military and foreign policy objectives may be defended in their own right. The Constitutional Convention recognized the distinction between political and commercial regulation and meant to ban only the latter. When Madison and Morris, speaking against the Clause, claimed that it prohibited all embargoes, ${ }^{37}$ its defenders corrected him immediately, insisting that actions justified by the war power lay beyond the Clause's scope. ${ }^{38}$

In recent decades most theorists have recognized an independent "foreign affairs power," 30 derived from the exigencies of America's position in the world as well as from the enumerated powers over war and foreign commerce. Actions justified by the foreign affairs power should not be exposed to an Export Clause challenge. Judicial review of an embargo, such as that currently imposed on trade with "independent" Southern Rhodesia, ${ }^{40}$ would compel the Court to assume the role of chief diplomat-a position for which the "Judiciary has neither aptitude, facilities nor responsibility." 41

[36.] A requirement that the treaty be signed by nations purchasing at least five per cent of the export controlled would eliminate blatant frauds on the Treaty Power.

[37.] 2 FARRAND, op. cit. supra note 12, at 360-61.

[38.] Id. at $361-62$.

[39.] See McDougal \& Associates, Studies in World Public Order, 404.718 (1960).

[40.] On March 18, 1966, the Department of Commerce imposed export controls on all exports to Southern Rhodesia and announced it would permit only those shipments which were necessary for essential humanitarian or educational projects. 75 DEP'T OF COMMERCE QUARTERLY REP. ON EXPORT CONTROLS 28 (1966).

[41.] Chicago \& Southern Airlines, Inc. v. Waterman S.S. Corp., 338 U.S. 108, 111 (1948), 


\section{Export Controls}

Where none of these rationales apply-as they do not in the case of quotas imposed to ameliorate domestic scarcity-export limitations should be struck down. Otherwise, the mere fact that restrictions have taken forms unforeseen in 1787 would suspend the operation of a constitutional provision whose policies are as relevant today as they were when it was first adopted.

See Scharpf, Judicial Review and the Political Question: A Funclional Analysis, 75 YaLE L.J. 517, 573-83 (1966). 